\title{
The Theory of Increasing Misery and the Critique of Capitalism
}

One of Lohmann's main ideas, as discussed earlier, was that, inherent in Marx's presentation, there are elements of critique which can be called transcending. These elements can be localised in the discussions of the fate of the working class and of the forces and struggles of opposition in capitalism. The normative standards of the participants present another form of critique of capitalism different from that of immanent critique. In Die Revolution in der Theorie von Karl Marx [The Revolution in the Theory of Karl Marx], Sieferle ${ }^{1}$ interpreted Marx's discussion of the general law of accumulation in a rather similar sense. To him, there is inherent, and partly hidden, in Marx's presentation a phenomenological level, a description of the experience of the wage workers of the exploitation and repression of capitalism which justifies Marx's expectations of the increasing revolutionary consciousness of the working class.

Sieferle's starting point was a problem connected with the revolutionary perspective in Marx's Capital. According to Sieferle, Marx was - at his best - able to determine the foundations of the objective reified thought forms produced by the capitalist mode of production and to show how the consciousness of the owners of different revenue sources (capital, land, labour) is system affirmative. On the other hand, Marx was forced to argue the necessity of the development of the revolutionary consciousness of the working class because of his historico-philosophical preconceptions. His expectations of the development of revolutionary consciousness were based on the analysis of capital accumulation. The theories of collapse and immiseration, as formulated at the end of the first volume of Capital, can be understood to determine both the objective and subjective limits of capitalism. The subjective experience of the growing misery of the wage workers is the basis of experience [Erfahrungsbasis] necessary for the development of a non-affirmative consciousness. This made it reasonable and justifiable for Marx to cherish his revolutionary hopes and expectations despite the seemingly iron-cage character of capitalism.

Sieferle's interpretation is interesting because it problematised some of the central themes of the theory of the capitalist collapse. According to Sieferle, in

1 Sieferle 1979. 
Capital Marx was only developing the inner contradictions of capitalism. The presentation did not seem to include any phenomenological level on which the analysis of the development of a revolutionary consciousness could be based. The secret or mystery of surplus production and exploitation can be revealed only through scientific analysis of the essence of capitalism; they always remain hidden from the everyday consciousness. ${ }^{2}$ The everyday experience of a wage worker does not include any such experience that could directly reveal the exploitative nature of capitalism. The problem could be formulated even more generally: is the exploitative nature of capitalism something that is revealed only to a scientist who is able and willing to follow the categorical exposition of the critique of political economy? ${ }^{3}$ What, then, is the revolutionary perspective in Capital?

Marx's Capital did, however, according to Sieferle, include such a phenomenological level after all. It did analyse the fate of the working class under capital accumulation. Marx was, indeed, describing the purpose of his further presentation at the beginning of the chapter on the general law of capital accumulation as follows:

In this chapter we consider the influence of the growth of capital on the lot of the labouring class. The most important factor in this inquiry is the composition of capital and the changes it undergoes in the course of the process of accumulation. ${ }^{4}$

In Sieferle's opinion, such considerations were unnecessary in Marx's earlier studies because the proletarian situation was characterised as one of total negativity:

The negativity of the proletarian situation as determined in the early concept of the materialistic theory of bourgeois society [i.e. in The German Ideology - J.G.] excluded the possibility of the continuous survival of

2 Cf. Marx's formulation in Capital: 'For the rest, in respect to the phenomenal form, "value and price of labour", or "wages", as contrasted with the essential relation manifested therein, viz., the value and price of labour-power, the same difference holds that holds in respect to all phenomena and their hidden substratum. The former appear directly and spontaneously as current modes of thought; the latter must first be discovered by science. Classical Political Economy nearly touches the true relation of things, without, however, consciously formulating it. This it cannot, so long as it sticks in its bourgeois skin' (Marx 1974-2004l, p. 542).

3 See Lange 1980, p. 214.

4 Marx 1974-2004l, p. 6o7. 
a fully developed capitalistic society ... This society must have been destroyed at the very moment the proletariat had developed into a socially relevant class. $^{5}$

The analysis in Capital comes to a different conclusion: the surface of bourgeois society forms an effective legitimation instance and all experiences are reflected through the mystified forms of its surface. If the ideas of freedom and equality of the commodity owners are preserved intact in capitalism, as Marx thought, one would have expected him to have paid more explicit attention to the problems of the possible destruction of the reified consciousness. Indeed, one would have expected Marx to include in his presentation in Capital a phenomenology of class consciousness that would have shown how the mystification of the thought forms could be destroyed and the universal consciousness of the historical nature of capital enfolded. ${ }^{6}$

Sieferle looked for the reasons for the neglect of an explicit discussion of the problem in Capital in the historical situation of the workers' movement in Marx's day. The practical evidence of the socialist movement was so obvious that it would have been uninteresting for Marx to try to justify theoretically the practical possibility of a revolutionary labour movement. According to Sieferle, it was the expanding and continuing reproduction of capital as experienced in England which, however, should have led Marx to problematise the question of system-conforming behaviour and consciousness of the working class. In Sieferle's opinion, from today's perspective it is quite clear that Marx had strong illusions about the revolutionary substance of this movement. And it has become almost commonplace to assert that Marx was taking the birth pains of capitalism to be its death agony. ${ }^{7}$

The nearest Marx ever came to the presentation of the problem of revolution in Capital was his analysis of the situation of wage workers under the law of capital accumulation. The tendential law of the falling rate of profit shows the objective limits of capital reproduction: in its everlasting hunger for surplus value by increasing the productivity of labour and, consequently, by increasing the share of relative surplus value, capital increasingly dismisses its own living

5 Sieferle 1979, p. 171. As Marx and Engels wrote in The German Ideology, 'only the proletarians of the present day, who are completely shut off from all self-activity, are in a position to achieve a complete and no longer restricted self-activity, which consists in the appropriation of a totality of productive forces and in the thus postulated development of a totality of capacities' (Marx and Engels 1974-2004c, pp. 87-8).

6 Sieferle 1979, p. 172; cf. Scharrer 1976, pp. 20-1.

7 Sieferle 1979, pp. 172-3. 
basis, labour power. ${ }^{8}$ If this tendency towards falling rate of profit shows the objective limits of capitalism, the law parallel to it, the capitalist law of relative overpopulation, shows the subjective limits of capitalism.

After abandoning the Ricardian position of the determination of wages through the physical existence minimum and the iron law of wages in the $1850 \mathrm{os},{ }^{9}$ Marx no longer adhered to a straightforward theory of the continuously growing misery of the wage workers. The wage worker does not necessarily represent absolute poverty any more, as he did in Marx's earlier writings. The increasing productivity of labour makes it possible for the real wages (and consumption) of the workers to rise even as the value and price of their labour power decrease and the rate of surplus value increases. Consequently, the worker does not in this respect necessarily have any subjective experience either of the contradictory character of the capital relation or of any direct immiseration of his or her economic or social position:

At the moment where immiseration is only seen in relation to the development of capital, but where living standards rise, the theory of immiseration can no longer claim to provide anything towards explaining the coming into being of revolutionary consciousness. Any immiseration that is not perceived as such [sinnlich erfahren] cannot be an expression of 'necessity' as 'need'.10

The immiseration theory was, however, preserved intact in another way by Marx. Due to the increasing organic composition of capital (the relation of constant to variable capital), total capital accumulated faster than its variable

8 'Beyond a certain point, the development of the powers of production becomes a barrier for capital; hence the capital relation a barrier for the development of the productive powers of labour ... The last form of servitude assumed by human activity, that of wage labour on one side, capital on the other, is thereby cast off like a skin, and this casting-off itself is the result of the mode of production corresponding to capital; the material and mental conditions of the negation of wage labour and of capital, themselves already the negation of earlier forms of unfree social production, are themselves results of its production process. The growing incompatibility between the productive development of society and its hitherto existing relations of production expresses itself in bitter contradictions, crises, spasms. The violent destruction of capital not by relations external to it, but rather as a condition of its self-preservation, is the most striking form in which advice is given it to be gone and to give room to a higher state of social production' (Marx 1973, pp. 749-50). See Vygodskyi 1970, pp. 20-1; see also Schanz 1981, p. 289.

10 Sieferle 1979, p. 198; cf. Wagner 1976, pp. 15-16. 
part; as Marx understood it, the amount of employed workers does not increase intact with the accumulated capital:

On the one hand, therefore, the additional capital formed in the course of accumulation attracts fewer and fewer labourers in proportion to its magnitude. On the other hand, the old capital periodically reproduced with change of composition, repels more and more of the labourers formerly employed by it. ${ }^{11}$

A continuously increasing reserve army of unemployed workers follows from this:

The labouring population therefore produces, along with the accumulation of capital produced by it, the means by which it itself is made relatively superfluous, is turned into a relative surplus population; and it does this to an always increasing extent. This is a law of population peculiar to the capitalist mode of production ... ${ }^{12}$

The rationale of the increasing industrial reserve army from the point of view of capital is its influence on the demand and supply of labour power and, consequently, on the wage level. Wages are automatically kept in control. The price of labour power tends towards the existential minimum under circumstances of decreasing demand and increasing supply of labour power. The following formulation shows clearly, according to Sieferle, ${ }^{13}$ that Marx was, even in Capital, introducing the concept of growing misery, once again:

Accumulation of wealth at one pole is, therefore, at the same time accumulation of misery, agony of toil, slavery, ignorance, brutality, mental degradation, at the opposite pole, i.e., on the side of the class that produces its own product in the form of capital. ${ }^{14}$

The possibility of the experience of the 'universal negativity' of the position of the working class, which in Sieferle's opinion is a precondition of the destruction of capitalism, is after all a subjectively experienced phenomenon in Marx's

\footnotetext{
11 Marx 1974-2004l, pp. 622-3.

12 Marx 1974-2004l, p. 625.

13 See Sieferle 1979, pp. 201-2.

14 Marx 1974-2004l, p. 640.
} 
later thinking too, because of the growing army of unemployed and the consequent misery and suffering of the wage workers under capitalism. Thus Marx did not need to present any more specific problematisation of the development of the consciousness of the working class on a phenomenological level that would have shown how the mystification of the surface can be penetrated and overcome. ${ }^{15}$

Sieferle criticised Marx's presentation of the capitalist law of population or the law of relative overpopulation because it is based on the idea of the increasing organic composition of capital. The same critique that can be directed at the 'falling rate of profit' doctrine can be directed at the population law. A priori, one cannot forecast any necessity for a continuously growing reserve army. Sieferle's critique of this law was almost a standard one: only if the value composition of capital were necessarily to rise and only if the rate of surplus value were not to rise fast enough, would the expected conclusion follow. ${ }^{16}$

One could, however, easily add some more doubts about the validity of the law. Marx was drawing from it conclusions that quite obviously could be drawn only at a later stage of his presentation. The general law of accumulation was an absolute and abstract law, as pointed out by Wagner. ${ }^{17}$ The expected conclusions could possibly follow only after the introduction of the problems of realisation and competition, and so on. The accumulation of capital was analysed, in the first volume of Capital, in its 'pure form' and, consequently, it can only be shown that - in relation to its own growth - capital continuously strives to get rid of its own basis of value increase, namely living labour, by increasing both absolute and relative surplus value and the productivity of labour. From this one cannot draw any conclusions concerning the historical fate of the working class, even less concerning the necessity for any continuously increasing misery. All that Marx could say at this stage of his presentation was that there is a tendency towards the existence of a relative overpopulation, that is, relative to the accumulated capital; capital accumulates faster than employment increases. But at the same time, employment can be increasing as well, albeit at a slower rate. Even if one were to accept the doctrine of the increasing organic composition of capital, it would not be correct to deduce from it any empirical forecasts about increasing overpopulation and unemployment, even less about any necessary decrease in the real wages of labour power or the increasing misery of the proletariat. And it is in principle as impossible to have

\footnotetext{
15 Sieferle 1979, p. 202.

16 Sieferle 1979, pp. 162-3.

17 Wagner 1976, pp. 79-81.
} 
any experience of the relative - that is, relative to the reproduction of capital overpopulation and relative pauperisation of the proletariat as it is to experience the growing relative exploitation (or 'relative immiseration').

Whatever one thinks about the doubts over the nature of the general law of accumulation, Sieferle's interpretation is in any case interesting because he claimed that Marx's Capital included a phenomenological level of presentation relevant to the development of class consciousness. In analysing the consequences of capital accumulation, Marx was explicitly discussing the historical fate of the proletariat under capitalism. More specifically, Marx was trying to show that the inner contradictions and limitations of the production of surplus value come to appearance on the surface of society in an empirically apprehensible way, as the misery and poverty of the workers. Thus the universal negativity inherent in the social category of wage labour can be experienced by the majority of the population; the wage workers come to realise that the capital relation must be overthrown to allow the free development of the individual. The wage worker as an 'absolute pauper' representing 'absolute negativity' is not only something that scientific analysis of the essence of capitalism can reveal. It is also something that every worker can and must feel in her or his own body and soul.

One could claim that the role of the theory of immiseration in Second International Marxism, and in Kautsky's thinking specifically, is very similar to that explicated by Sieferle in discussing Marx's Capital. Just as crisis development, centralisation of capital, and the generalisation of wage labour were thought to reveal the objective limits of capitalism, so the increasing misery was thought to express its subjective limits. The revolutionary consciousness is born out of the insight that capitalism has nothing to offer the working masses. While making the capitalists richer, wage workers are doomed to ever increasing misery. As already pointed out, the central role of the law of the increasing misery of the working class was accepted to be a crucial element of Marxism by both the orthodox Marxists and the 'revisionists' of the Second International. They only disagreed over the empirical validity of the law.

However, it may be doubted whether Marx's discussion of the capitalist law of population could in any way be understood either as a phenomenological level of the analysis of consciousness (Sieferle), or as a discussion of the normative standards of the participants forming part of Marx's transcending critique (Lohmann). The discussion is closely connected with the postulates and conclusions of classical theories of bourgeois society. It is here suggested that Marx's discussion of the general law of accumulation and the fate of the working class in Capital should be considered strictly within the context of his critique of political economy. Marx was, first of all, criticising the respective 
laws of Ricardo (1817) ${ }^{18}$ and Malthus (1798), ${ }^{19}$ and trying to prove that the tendency towards increasing overpopulation and the falling rate of profit are not eternal natural laws, but rather, on the contrary, historical laws which are specific to capitalism. For Ricardo, the falling rate of profit resulted from the diminishing productivity of land taken into use cumulatively. ${ }^{20}$ In Capital, Marx was directly commenting on Malthus:

The labouring population therefore produces, along with the accumulation of capital produced by it, the means by which it itself is made relatively superfluous, is turned into a relative surplus population; and it does this to an always increasing extent. This is a law of population peculiar to the capitalist mode of production and in fact every special historic mode of production has its own special laws of population, historically valid within its limits and only in so far as man has not interfered with them. ${ }^{21}$

There is, however, yet another context which is even more relevant to the interpretation of Marx's law of accumulation and overpopulation. In Capital, Marx stated:

The action of the law of supply and demand of labour on this basis completes the despotism of capital. As soon, therefore, as the labourers learn the secret, how it comes to pass that in the same measure as they work more, as they produce more wealth for others, and as the productive power of their labour increases, so in the same measure even their function as a means of the self-expansion of capital becomes more and more precarious for them; as soon as they discover that the degree of intensity of the competition among themselves depends wholly on the pressure of the relative surplus population. ${ }^{22}$

The law of supply and demand of labour power in a sense completes the analysis of the despotism of capital in Marx's critique of political economy:

\footnotetext{
18 Ricardo 1971.

19 Malthus 1970.

20 See Ricardo 1971, pp. 71-2; cf. Marx 1973, pp. 6o6-7.

21 Marx 1974-2004l, pp. 625-6. The translation confuses the two sentences at the end. The original German version of Das Kapital finishes with 'an abstact law of population only exists for plants and animals as far as man has not historically interfered with them' (Marx 1969b, p. 669).

Marx 1974-2004l, p. 634 .
} 
as soon as wage workers come to recognise that they, in fact, produce riches alien to themselves in the form of capital, while becoming poorer themselves, capitalism has come to an end. By reproducing capital on an enlarging scale, they reproduce their own situation as wage workers, a situation characterised by both insecurity and brutality.

In the Economic and Philosophical Manuscripts of 1844, the same idea was already formulated in abstract terms: "The worker becomes all the poorer the more wealth he produces, the more his production increases in power and size.'23 In Grundrisse, the conclusion can be found in a more developed form already resembling Marx's analysis in Capital:

He [the worker] has produced not only the alien wealth and his own poverty, but also the relation of this wealth as independent, self-sufficient wealth, relative to himself as the poverty which this wealth consumes, and from which wealth thereby draws new vital spirits into itself, and realizes itself anew. ${ }^{24}$

And further:

It here becomes evident that labour itself progressively extends and gives an ever wider and fuller existence to the objective world of wealth as a power alien to labour, so that, relative to the values created or to the real conditions of value-creation, the penurious subjectivity of living labour capacity forms an ever more glaring contrast. ${ }^{25}$

The discussion of the general law of accumulation and the fate of the working class in Capital can then be interpreted to be a more developed formulation of the above ideas. ${ }^{26}$ By showing the mechanism through which the reproduction and accumulation of capital makes the capitalist richer and the worker poorer, Marx is concluding his critique of natural rights thinking and classical political economy. The analysis of the reproduction of capital proved how the value

\footnotetext{
23 Marx 1974-2004b, pp. 271-2.

24 Marx 1973, p. 453.

25 Marx 1973, p. 455.

26 In Critique of the Gotha Programme, Marx approvingly referred to a formulation according to which the misery of the working class is continuously increasing while the capitalists are becoming all the richer: 'In proportion as labour develops socially, and becomes thereby a source of wealth and culture, poverty and destitution develop among the workers, and wealth and culture among the nonworkers' (Marx 1974-2004f, pp. 82-3).
} 
increase of capital takes place at the cost of living labour, and how wage labour continuously reproduces the social force that dominates the life activity of the worker. The production of a relative overpopulation, the other side of the accumulation of capital, shows furthermore that while continuously reproducing the conditions of further accumulation of capital, wage labour simultaneously reproduces its own relative superfluousness. The wage worker thus continuously reproduces the relation of domination of capital over herself, or the domination of dead over living labour, a domination which most concretely comes into appearance as the relative overpopulation of workers:

But in fact, it is capitalistic accumulation itself that constantly produces, and produces in the direct ratio of its own energy and extent, a relativity redundant population of labourers, i.e., a population of greater extent than suffices for the average needs of the self-expansion of capital, and therefore a surplus population. ${ }^{27}$

The other side of the accumulation of capital is the accumulation of misery as explicitly stated by Marx: 'It establishes an accumulation of misery, corresponding with accumulation of capital'.28

In Marx's critique of capitalism, the original identity of labour, property and use value as postulated by John Locke and Adam Smith was definitely broken. Rather than increasing the conveniences of human life by adding more labour to nature's products as promised by Locke, those who work are deprived of even the mere necessities of life and of the very means of their living. Neither does the increasing wealth of a nation - followed by inequality of property guarantee that a human existence will extend even to the lowest ranks of people, as promised by Smith. The general well-being of the greatest number does not follow from the growing wealth of a nation. The accumulation of capital results more in the most inhuman existence of the greatest number of people, the working class. In Marx's analysis, the accumulation of capital completes the despotism of capital, ${ }^{29}$ and proves the dependence of the wage worker on the conditions of the reproduction of capital leading to the utmost brutality and insecurity of the whole life situation of the wage workers. ${ }^{30}$

27 Marx 1974-2004l, p. 624.

28 Marx 1974-2004l, p. 640.

29 Nielsen 1980.

30 The list of the 'vices' of capital quoted by Marx is impressive: 'within the capitalist system all methods for raising the social productiveness of labour are brought about at the cost of the individual labourer; all means for the development of production transform 
At the end of the first volume of Capital, Marx thus implicitly claimed that bourgeois society does not keep its promise of reason as formulated by classical thinking, and the legitimation of private property, money and capital through their social consequences, the human existence of humankind, cannot be justified. However, Marx was clearly exaggerating his case, while emphasising the almost continuous and inevitable immiseration of the working class. ${ }^{31}$

But it clearly was not sufficient for Marx only to prove that wage labour produces riches in a form alien to itself and that, whether or not better paid, wage labour continuously reproduces the capital relation - and the conditons of its own further existence - on a larger scale. Marx did not only stop at the point of proving that wage labour both reproduces on the one side more capitalists and on the other side more wage workers and the continuous dominance of capital over itself, as stated at the beginning of the chapter on the general law of accumulation:

The more or less favourable circumstances in which the wage working class supports and multiplies itself, in no way alter the fundamental character of capitalist production. As simple reproduction constantly reproduces the capital relation itself, i.e., the relation of capitalists on

themselves into means of domination over, and exploitation of, the producers; they mutilate the labourer into a fragment of a man, degrade him to the level of an appendage of a machine, destroy every remnant of charm in his work and turn it into a hated toil; they estrange from him the intellectual potentialities of the labour process in the same proportion as science is incorporated in it as an independent power; they distort the conditions under which he works, subject him during the labour process to a despotism the more hateful for its meanness; they transform his life-time into working-time, and drag his wife and child beneath the wheels of the Juggernaut of capital' (Marx 1974-2004l, p. 639).

31 As shown by Carlsen et al. (1980; see also Schanz 1981), there is an important dimension in Marx's thinking concerning the civilisatoric dynamism of capitalism that is especially pronounced in the Grundrisse. According to Marx, the development of a free and rich individuality with universal needs and capacities results from the civilisatoric influence of capital. Marx never explicitly reflected on the relation between his conception of the civilisatoric influence of capital in Grundrisse and the results of his analysis of the fate of the working class in Capital. At first sight, there would seem to be in Marx's thinking a duality similar to that presented by Kautsky concerning the position of the working class in capitalism. According to Kautsky, there are both elevating and repressive tendencies operating in capitalism. Whereas the elevating tendencies in Kautskys argumentation are always connected with the struggle of the working class against capitalism, in Marx's thinking they are, however, inherent in the very civilisatoric dynamism of capital. 
the one hand, and wage workers on the other, so reproduction on a progressive scale, i.e., accumulation, reproduces the capital relation on a progressive scale, more capitalists or larger capitalists at this pole, more wage workers at that ... Accumulation of capital is, therefore, increase of the proletariat. ${ }^{32}$

Evidently Marx wanted to prove more than could actually be proved on the basis of his premises. He wanted to prove that the existence of the proletariat, the greatest number of the people within capitalism, is inclined to become more brutal and inhuman in a very concrete sense. Thus Marx opened up his case for a direct empirical interpretation - and falsification - of his theory and a historical critique of it. At least certain parts of his analysis can legitimately be understood to form a historical prognosis of the ever-worsening economic and social condition of the working class in capitalism. And it was the Second International Marxism that adopted this interpretation and prophecy as its own and absolutised it into the very cornerstone of its scientific socialism.

Marx 1974-2004l, p. 6o9. 